\title{
Intellect and the One in Porphyry's Sententiae
}

\author{
John Dillon \\ Trinity College, Dublin
}

\begin{abstract}
This article seeks to provide some support for the troublesome report of Damascius in the De Principiis that, for Porphyry, the first principle is the Father of the Noetic Triad-and thus more closely implicated with the realm of Intellect and Being than would seem proper for a Neoplatonist and faithful follower of Plotinus. And yet there is evidence from other sources that Porphyry did not abandon the concept of a One above Being. A clue to the complexity of the situation may be provided by a passage from Proclus (In Parm. 1070, 155ff. Cousin) which criticises him for making the One the subject also of the Second Hypothesis of the Parmenides. Here, I consider a series of passages from Porphyry's Sententiae which seem to indicate a doctrine of the One essentially faithful to that of Plotinus, but modulated in the direction of closer linkage to the levels of reality below it.
\end{abstract}

\section{Keywords}

One, transcendence, hypostases, God, Intellect, Plotinus

The stimulus to these reflections is actually a passage, quite well known by now, from Damascius' Problems and Solutions on the First Principles (\$43, I 86. 8-15 Ruelle = Fr. 367 Smith), where, in the process of contrasting Porphyry and Iamblichus on the question of first principles, he seems to allege a remarkable degree of conflation on Porphyry's part between the First Principle, or One, and the level of reality below it, that is, the realm of the Intellect; for Porphyry, he says, "the single first principle of all things is the Father of the

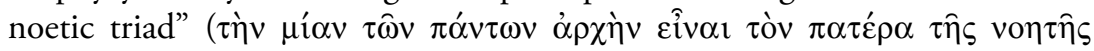
$\tau \rho \jmath \alpha ́ \delta о \varsigma)$. 
In a number of articles, ${ }^{1} \mathrm{I}$ have maintained the position that this testimony, reinforced by a significant passage of Proclus' Parmenides Commentary (p. 1070, 15ff. Cousin), ${ }^{2}$ where he is plainly referring to Porphyry, does indeed indicate that Porphyry wishes, at least to some extent, to 'telescope' (to adopt a term of A.C. Lloyd's) 3 the first two Plotinian hypostases, by propounding the position that the One, in its 'positive' creative aspect, may be identified with the highest element of the intelligible realm, OneBeing, or, in Chaldaean terms, the 'Father' of the triad of 'Father-Life (or Power)-Intellect'. This position also involves (and that is what concerns Proclus) the assertion that the subjects of the first two hypotheses of the Parmenides are substantially the same- the One in two different aspects.

This does not of course mean that Porphyry has rowed back from Plotinus' epoch-making assertion of a One above Being and Intellect. We have enough evidence, from such texts as surviving fragments of his Philosophic History (Frs. 220-3 Smith), that he maintained the existence of such a first principle, and this is confirmed by a perusal of the Sententiae. What I wish to do on the present occasion is to examine all of the passages in the Sententiae where the One unequivocally appears as distinct from and superior

1) 'Logos and Trinity: Patterns of Platonist Influence on Early Christianity', in The Philosophy in Christianity, ed. G. Vesey (Cambridge 1989), 1-13, repr, in The Great Tradition (Aldershot 1997), Essay VIII; 'Porphyry's Doctrine of the One', in Sophiés Maiétores: hommage à Jean Pépin, edd. M.-O. Goulet-Cazé, G. Madec \& D. O’Brien (Paris 1992), 35666, repr. In The Great Tradition, Essay XVI; 'What Price the Father of the Noetic Triad? Some Thoughts on Porphyry's Doctrine of the First Principle', in Studies on Porphyry, edd. G. Karamanolis \& A. Sheppard (London, 2007), 51-9.

2) "We shall therefore be very far from making the primal god the summit of the intelligible world, as I observe to be the practice of some leading authorities on divine matters ( $\tau \mathrm{\imath} \omega \hat{\omega} v \dot{\varepsilon} v$ $\theta \varepsilon o \lambda o \gamma i \alpha \underline{\alpha} \pi \rho \omega \omega \tau \varepsilon v \sigma \alpha ́ v \tau \omega v)$, and making the Father of that realm the same as the cause of all things. For this entity is a participated henad. After all, he is called an 'intelligible father' and 'the summit of the intelligible world', and even if he is the principle of coherence for the whole intelligible world, yet it is as its father that he is so. The primal god, however, who is celebrated in the First Hypothesis [sc. of the Parmenides] is not even a father, but is actually superior to all paternal divinity. The former entity is set over against its 'power' and its 'intellect', of whom it is said to be the father, and with those it makes up a single triad, whereas this truly primal god transcends all contrast and relationship with anything, so a fortiori it is not an intelligible father."

3) In his contribution to the Cambridge History of Later Greek and Early Mediaeval Philosophy, ed. A. H. Armstrong, Cambridge, 1967, ch. 18, pp. 287-93. 
to Intellect, to see what conclusions we may draw about Porphyry's overall view of the relations between the two.

We first meet the One in Sentence 10, which is Porphyry's version of the Numenian principle, "All things are in all, but in a manner appropriate to the essence of each" (Fr. 41 Des Places):

All things are in all, but in a mode proper to the essence of each: in the intellect, intellectually; in the soul, discursively; in plants, seminally, in bodies, imagistically; and in the Beyond, non-intellectually and supra-essentially

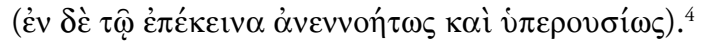

Here, admittedly, we find the term 'the Beyond', rather than the One, but there is really no room for doubt that it is the One, or the Good, that is being referred to, the term epekeina being borrowed ultimately from Rep. VI 509B (though the use of it as a substantive is post-Platonic). The two remarkable adverbs that accompany it serve to drive home the point

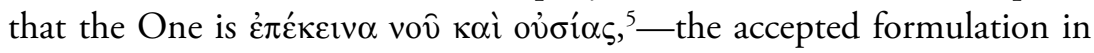
the later Platonic tradition. However, our chief focus of interest here must be in the fact that Porphyry wishes to assert that, in some way, the One contains 'all things', making it the source, albeit in a mode transcending intellection and being, of the totality of things in the universe.

This is not actually at odds with the doctrine of Plotinus, even if stated somewhat more scholastically. For Plotinus, after all, the One is dynamis tøn pantôn, all things in potency as well as potentiality, ${ }^{6}$ while yet being

\footnotetext{
4) All translations are my own, taken from my English translation of the Sententiae appended to the great CNRS edition of the work, Porphyre, Sentences, ed. L. Brisson et al., 2 vols., Paris: Librarie philosophique J. Vrin. 2005, to the excellent commentaries of which I am much indebted.

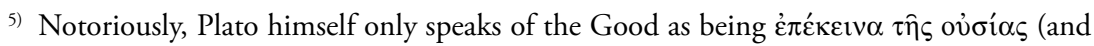

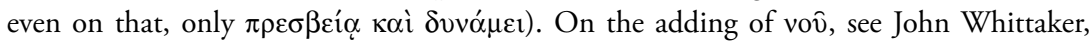

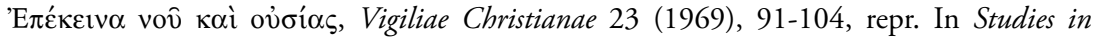
Platonism and Patristic Thought (Aldershot, 1984), Essay XIII.

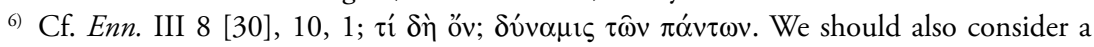
significant passage from an earlier tractate, IV 8 [6], 6, where Plotinus could be understood to be saying that all things are somehow contained within the One; but his point there is rather a negative one, that nothing at all would have arisen if the One had not been pos-

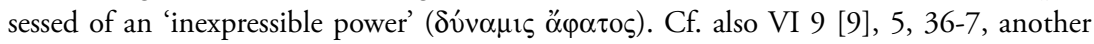
early passage.
} 
prior to intellect and essence, and thus wholly transcendent and 'other'. This is in fact precisely the tension within Plotinus' concept of the One that Porphyry, I would suggest, is concerned to resolve, so far as that can be done.

At any rate, the epekeina recurs in Sentence 12, in the context of pointing out that 'life' is an homonymous concept. We are told that "life has one meaning in the case of a plant, another in the case of an animate being, and another in the case of an intelligent being; one in the case of nature, another in that of soul, another in that of intellect, and another yet in the case of

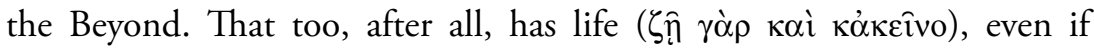
none of the things which come after it possesses a life which is comparable to it."

Here, even though stress is laid on the very special quality of the life of the Beyond, Porphyry has no hesitation is ascribing to it some form of life. This assertion certainly goes against at least the prevailing view of Plotinus, ${ }^{7}$ as expressed in such passages as III 9 [13] 9, 17 and III 8 [30], 10, 28-31. In the former passage, in the context of denying to the One any form of intelligizing or consciousness, he says: "What then? Is it not alive either? No, it cannot be said to live, but if it can, only in the sense that it gives life." 8

This last phrase might seem to constitute a significant qualification, in that one could claim that the One lives 'causatively', but it goes against another principle of Plotinus, enunciated in VI 7 [38], 17, 4, where he declares that "it is not necessary that a thing possesses what it gives" (引̀ ov̉

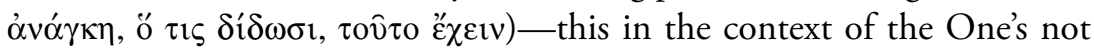
having within it the Forms, which it imparts to Intellect through the process of Intellect's contemplation of it.

In the somewhat later tractate III 8, we find: "It (sc. the One) is certainly none of the things of which it is the origin; it is of such a kind, though nothing can be predicated of it, not being, but substance, not life, as to be above all of these things." This lays it on the line pretty firmly, one would think, though it is true that in the early tractate V 4 [7], 2, 38ff. he

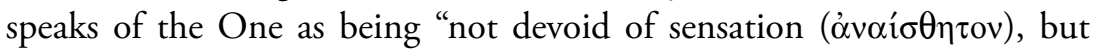

\footnotetext{
7) I am indebted here to the most useful note of Michel Narcy, in the CNRS commentary on the Sentences, ad loc.

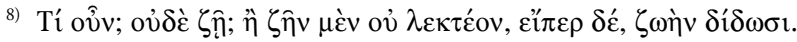


there is life in it" - though Plotinus here stresses that all the qualities attributed to the One here must be understood in a different sense to anything below it. It is from such a passage that Porphyry could derive support for his assertion here.

The One figures again in Sentence 25, which is concerned with the mode of acquaintance that we might have with the One-still referred to as $\tau$ ò

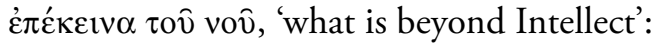

On the subject of that which is beyond Intellect, many statements are made on the basis of intellection, but it is contemplated $(\theta \varepsilon \omega \rho \varepsilon i \tau \alpha)$ by a non-intel-

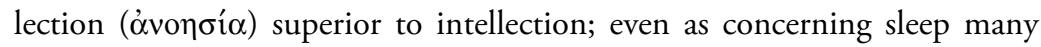
statements may be made in a waking state, but only through sleeping can one gain knowledge and comprehension ( $\gamma v \hat{\omega} \sigma ı \varsigma \kappa \alpha \grave{\imath} \kappa \alpha \tau \dot{\alpha} \lambda \eta \psi(\varsigma)$; for like is known by like, because all knowledge consists of assimilation to the object of knowledge.

Here Porphyry, following Plotinus, attempts to come up with a plausible formula for characterizing our knowledge of the One, which must be a level of consciousness distinct from, and superior to, intellection. Porphyry comes up here with what appears to be a neologism, anoesia, ${ }^{9}$ to describe this, though he makes use of a similar term, agnosia, in his Parmenides Commentary (IX 24-6). ${ }^{10}$ The comparison with the sleeping state is most interesting and original, though it recalls to some extent Plotinus' distinction in Enn. VI 7, 35, between intellect sober and intellect drunk, through the latter of which only can one cognize the One. The reminder that 'like is known by like' is presumably a way of suggesting the existence of a onelike faculty in us, such as is also suggested by Plotinus on occasion (e.g. III 8, 9, 15-24; VI 9, 11, 32).

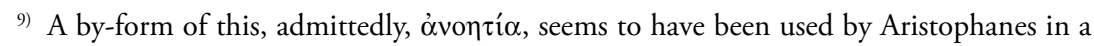
fragment of a lost play (Fr. 746 Kock), but it is most unlikely that Porphyry, learned though he was, would have taken his authorization for innovation from that source.

10) I have expressed myself in favour of the Porphyrian nature of this document (as proposed originally by Pierre Hadot) elsewhere (e.g. 'Porphyry's Doctrine of the First Principle' [n. 1 above], p. 54, n. 10), and am disinclined to repeat the arguments here. Suffice it to say that there are no doctrinal grounds for disputing Porphyrian authorship, and various details of language which support it. 
In Sent. 26, also, there is a brief reference to the sort of cognition we might have of the One, where Porphyry is making a distinction between the two kinds of not-being, that which is above Being and that which is a

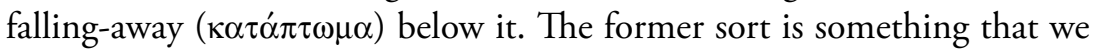

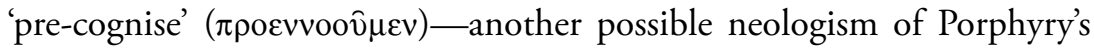

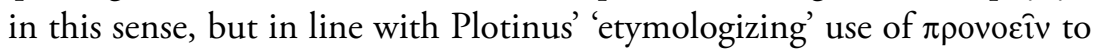
describe the 'pre-thinking' proper to our cognition of the One at V 3, 10, 44. So, while the One is presented here as a transcendent, 'super-ontic' Non-Being ( noia, which places it at the positive end of the spectrum of the Plotinian metaphysics of the One.

In Sentence 30, on the other hand, we find the One, here designated 'the First' ( $\tau$ ò $\pi \rho \hat{\omega} \tau o v)$, as the culmination of a sequence of 'hypostases', all of which direct their attention upwards, rather than downwards to their inferiors:

Of those hypostases ${ }^{11}$ which are universal and perfect, none has its attention turned ( $\dot{\varepsilon} \pi \varepsilon ́ \sigma \tau \rho \alpha \pi \tau \alpha \iota)$ towards its own offspring, but all direct themselves upwards towards their generators, even down to the body of the cosmos; for it, in its perfection, directs itself towards its soul, which is intellectual, and for this reason performs a circular motion, while its soul directs itself towards the Intellect, and the Intellect towards the First. Each of these entities, then, penetrates as far as this (sc. the First), beginning from the lowest, according to its capacities. The ascent to the First, however, is either immediate or mediated

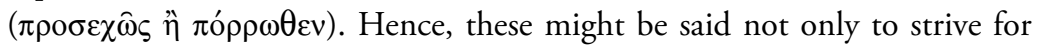
God, but also to enjoy him according to their capacities.

This is the only passage in the Sentences, as is noted by Luc Brisson in his comments to the CNRS edition ad loc., where one finds the ascending series of entities: World Body, World Soul, Intellect, One. The suggestion is also that the reversion to the One is rather less problematic than it is in Plotinus. At any rate, Intellect is asserted to penetrate to ( One $\pi \rho 0 \sigma \varepsilon \chi \omega \hat{\omega}$, which is, it seems to me, rather more than Plotinus would wish to assert. We also find the One denominated 'God', and an object not

11) Or perhaps just 'realities', if one wishes to confine the term 'hypostasis' to the three principal hypostases, of which the body of the cosmos is not one. 


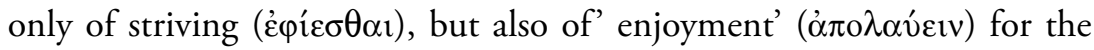
levels of being below it - the latter a rather strong term!

The One also appears as God in the next Sentence (31), at the head of a sequence of hypostases:

God is everywhere because he is nowhere, and Intellect is everywhere because it is nowhere, and Soul is everywhere because it is nowhere. But God is everywhere and nowhere in respect of all things, since all things come after him ${ }^{12}-$ it is his characteristic to be only as he is and as he wills; $;{ }^{13}$ while Intellect is in God, on the one hand, but is everywhere and nowhere in respect of what comes after it; and Soul is in Intellect and God, on the one hand, but everywhere and nowhere in respect of body; and as for body, it is both in Soul and in Intellect and in God.

Porphyry goes on to say that "all things existent and non-existent ( $\pi \alpha$ ó $\tau \alpha$

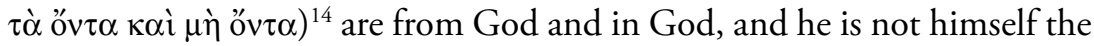
existents and non-existents, nor is he in them-for if he were merely everywhere, he himself would have been all things and in all things; but since he is also nowhere, all things come to be through him and in him, because he is everywhere, but other than him, because he himself is nowhere." I would suggest that Porphyry's use of 'everywhere' and 'nowhere' here in respect of the One is designed to preserve the One's transcendence 'in itself', while allowing for its omnipresence 'in relation to others', in line with his interpretation of the first two hypotheses of the Parmenido.

Lastly, in Sentence 43, the One is introduced, this time under its own name, so to speak, though even now somewhat incidentally, as the premiss in an argument to prove that Intellect cannot be the first principle, because it is many:

\footnotetext{
12) This slight over-translation of $\tau \hat{\omega} v \mu \varepsilon \tau^{\prime} \alpha \hat{\tau} \tau \hat{\jmath} \pi \alpha \alpha^{\prime} \tau \omega v$ is justified, I think, to catch the full implications of the phrase.

13) For a full discussion of this cryptic remark, see Wilfried Kühn's most useful note at II 616-17 of the CNRS commentary. The 'is' used here in respect of God is not to be seen as existential, so there is no contradiction with Sentence 36; and the reference to his 'will' is best taken against the background of Plotinus' discussion of God's free will in Enn. VI 8, ch. 11, 13-28.

14) It is not quite clear what 'non-existents' Porphyry has in mind here. Matter is one, no doubt; but perhaps also the Stoic incorporeals, such as void, time and lekta.
} 
Intellect is not the first principle of all things; for Intellect is many, and prior

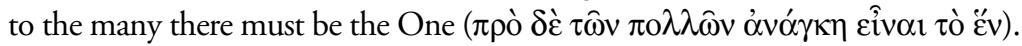

Admittedly, we cannot here be quite certain that Porphyry is not merely intending to say, just in general, that prior to any multiplicity there must be a unity, but in the present context he is inevitably also postulating the One, so we may leave the translation thus. This would, then, be the only occasion on which he mentions the One by name, rather than referring to it as $\tau$ ò $\dot{\pi} \pi \varepsilon ́ \kappa \varepsilon v v \alpha$ or $\tau$ ò $\pi \rho \hat{\omega} \tau o v$, or God.

At any rate, there can be no question but that in the Sententiae Porphyry fully recognizes the role of the Plotinian One, and thus that whatever is implied by the troublesome report in Damascius about his equating the first principle with the Father of the Intelligible Triad, it does not involve any radical retreat from the Plotinian position in a 'Middle Platonic' direction.

We can discern, however, I think, in these passages some degree of modification of Plotinus' position on the nature of the One, in the direction of relating it more positively to what is below it. This, we must specify, need not be taken as a contradiction of Plotinus-indeed that would be most unlikely for such a faithful follower as Porphyry—but rather, as in certain other areas (such as e.g. the doctrine of levels of virtue, in Sent, 32), as evidence of a concern to formalize his position somewhat.

Thus, for Porphyry, the One can be said to contain all things, albeit in a very distinctive and transcendent way (Sent. 10); it can be said to possess life, though once again in a mode quite peculiar to itself (Sent. 12); and we can have a sort of acquaintance with it, though this is characterized as anoésia, and compared to knowing about the state of sleep only through sleeping (Sent. 25), or proennoia, as in Sent. 26; while in Sents. 30 and 31 we see the lower hypostases portrayed as 'penetrating back' to the One, or as in some way being 'in' it. All this, I think, is relevant to what I take to be Porphyry's distinctive position on the subject matter of the first two hypotheses of the Parmenides, set out in his Parmenides Commentary-a position that much displeased Proclus, as we can see from his criticisms at In Parm, 1070, 15ff. Cousin-that both hypotheses actually have as their subject the One, but in different aspects: the first the One in itself, as radically transcendent and other; the second the One in its active, creative aspect, in relation to all things. It is rather this second aspect of the One that 
we come upon, I would suggest, in the Sententiae, and it is in this aspect that it can fitly be characterized as the Father of the noetic triad-and, in a mediated way, of all other things.

\section{Bibliography}

Brisson, L., et al. (ed.). Porphyre, Sentences, 2 vols., Paris: Librarie philosophique J. Vrin. 2005

Dillon, J. 'Logos and Trinity: Patterns of Platonist Influence on Early Christianity', in The Philosophy in Christianity, ed. G. Vesey (Cambridge 1989), 1-13, repr, in The Great Tradition (Aldershot 1997), Essay VIII

- 'Porphyry's Doctrine of the One', in Sophiés Maiétores: hommage à Jean Pépin, edd. M.-O. Goulet-Cazé, G. Madec \& D. O’Brien (Paris 1992), 356-66, repr. In The Great Tradition, Essay XVI.

- 'What Price the Father of the Noetic Triad? Some Thoughts on Porphyry's Doctrine of the First Principle', in Studies on Porphyry, edd. G. Karamanolis \& A. Sheppard, London: Institute of Classcial Studies, 2007, 51-9.

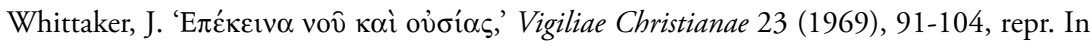
Studies in Platonism and Patristic Thought (Aldershot, 1984), Essay XIII. 